\title{
Identifying significant determinants for acceptance of nature reserves: A case study in the Stilfserjoch National Park, Italy
}

\author{
Georg Leitinger, Janette Walde, Roberta Bottarin, Gottfried Tappeiner \& Ulrike Tappeiner
}

Keywords: key factors, perception, local population, zoning, nature protection

\section{Abstract}

For the effective management of protected areas in inhabited and cultivated areas it is indispensible to know the factors on which the acceptance of the protected area depends. This study aimed at analysing the acceptance of the local population within one of the historical national parks of Italy, the Stilfserjoch National Park (NP). This NP is particularly suited to such an investigation for a number of reasons: it presents a very complex landscape and a wide altitude range; it is characterized by strong human influence and different land management types; some of the inhabitants within the NP belong to the Italian-, others to the German-speaking ethnic group and the NP covers three Italian regions, each with its own past and cultural history. We identified determinants of influence on the basis of a representative survey. Explorative analyses with discriminant analyses as classification method revealed a subordinated role for achieving acceptance of both the attitude towards nature and the work of the National Park Administration (NPA). According to our findings, perceptions in the local population are formed in a three-step-process starting with environmental education to identifying and answering the social needs of the residents to acknowledging personal needs by minimizing disadvantages for individuals. All in all, the results show that a survey of the population carried out in the presented way can make a major contribution to focusing the work of the NPA and to minimizing activities in 'fruitless tasks'.
Profile

Protected area

Stilfserjoch National Park

Mountain range

Alps

Country

Italy

\section{Introduction}

Reserves exist only thanks to human initiatives (Colchester 2004; Singh 1996; Terstad 1999; Trakolis 2001b; Treu et al. 2000; White \& Lovett 1999). Protected areas need strategies to gain acceptance among the local population in order to ensure support for their conservation aims and tasks (Colchester 2004; Grainger \& Grainger 2003; Job 1996; Singh 1996; White \& Lovett 1999). Analysing the theme of acceptance within conservation measures is not a new approach, but recently social and political sciences have begun to address conservation as research topic (West \& Brockington 2006). This development stems from the realization that conservation cannot be successful and sustainable without the acceptance of the local population (Schenk et al. 2007; Trakolis 2001a; Trakolis 2001b). This is especially true for European conservation areas where extensive zones without human impact can hardly be found anymore (Collin 1990; Hamin 2002; Trakolis 2001a; Trakolis 2001b; Treu et al. 2000).

Surveys indicate the discrepancy between high regard for conservation and strong objections as soon as concrete measures are to be realized (Brand 2001; Getzner \& Jungmeier 2002). This raises the following questions: 1) Which basic conditions have to be created by the NPA to ensure acceptance of the conservation area? 2) Which basic attitudes within the local population are necessary for such an acceptance?

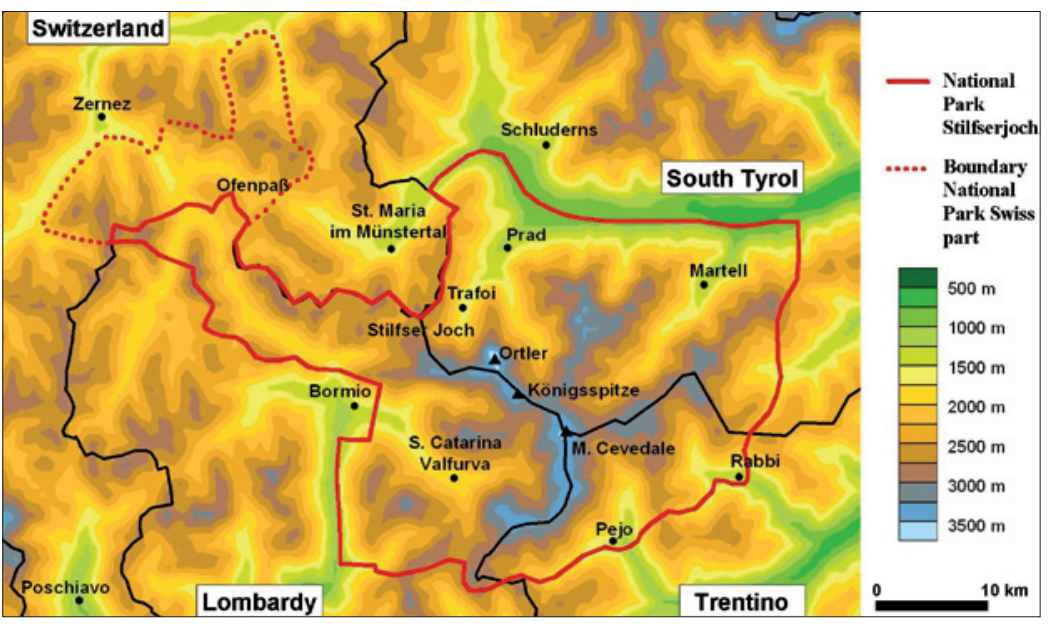

Figure 1 - The study area Stilfserjoch NP - location and size

Earlier investigations revealed the importance of the attitudes of the park residents and the necessity to involve the 'locals' in decision-making processes (Schenk et al. 2007; Trakolis 2001a; Trakolis 2001b). It is assumed that a corporate design and identity of the NPA increase the acceptance. Nevertheless, studies revealed that people themselves have to be convinced of the necessity of conservation to support the feasibility of nature reserves in the long run (Job 1996).

The aim of this study was to identify the determinants for acceptance in the Stilfserjoch NP, Italy. Given the park's shape and history, a study of acceptance is of 
particular interest in the Stilfserjoch NP for to the following reasons: 1) the Stilfserjoch NP with its wide altitude range and various land-cover types provides facilities for numerous activities which are partly restricted by regulations (Gafta \& Pedrotti 1997); and 2) two ethnic groups living and working within the park area are a special challenge for the NP management. Most studies on the acceptance among the local population were carried out in very large protected areas, mainly in developing countries (Burns \& Howard 2003; Campbell et al. 2000; Chapman 2003; Ferraro 2002; Seeland 2000; Sträde et al. 2000; Sträde \& Helles 2000; Wallner et al. 2007). Our study is one of the few to collect quantitative and qualitative data within a protected area in the Alps and the first one within the Stilfserjoch NP.

To evaluate perceptions of the Stilfserjoch NP and deduce indications for the NPA how to improve acceptance, we pursued the following objectives:

- Identification of decisive influence factors for the NP's acceptance;

- Statistical evaluation of perceptions and detection of general patterns of the acceptance of a nature reserve.

\section{Study area}

The Stilfserjoch NP covers an area of 134620 ha in the middle of the Central Alps, Italy, WGS84 $10^{\circ} 01^{\prime}-57^{\prime} \mathrm{E}, 46^{\circ} 16^{\prime}-45^{\prime} \mathrm{N}$ (Figure 1). The park includes the entire massif of the Ortles Cevedale group and its altitude ranges from $650 \mathrm{~m}$ to $3899 \mathrm{~m}$ (Ortler peak). The conservation area borders on to other reserves (Swiss National Park, Adamello-Brenta Nature Park, Adamello Regional Park) and is therefore of great strategic importance at its location in the centre of the Alps. The area was designated as National Park by the Italian government in 1935 and initially covered 96000 ha. In 1977, the park was extended to its current size. Since 1993, the three sections of the park have been managed in a unique form of administration of conservation areas in Italy, the Stilfserjoch NPA. By the international categories of the IUCN, the Stilfserjoch NP falls into protection category 5. The conservation area extends over two autonomous provinces (South Tyrol and Trentino) and one region (Lombardy). Linguistic, cultural, demographic and economical as well as landscape-ecological differences characterize the Stilfserjoch NP.

The park is spread across 24 municipalities. Two of them are located completely within the NP, a further two have more than $97 \%$ of their area located within the NP. Settlements, agricultural areas (in part intensive crops), industrial estates, ski lifts, quarries and hydro-electric power stations exert a considerable impact on the environment (DeBattaglia 1974).

For the Stilfserjoch NP, a park plan was defined as tool for organizing and zoning the park area. The preparation process of the park plan started in 1991 with its definition in the National Park Act and in 2005, mapping of the planned zoning was finished. In 2006, the local population as well as NGOs and stakeholders were given the chance to state their position about the park plan. In August 2009, final mapping and the implementation instructions for zoning the Stilfserjoch NP were completed by the NPA. To become operative, the park plan must yet be finally examined and passed by the Department of the Environment of Italy, which has not been done to date (March 2010). The park is to be divided into four zones with a protection status ranging from a strictly protected core zone (A) to a permanently settled area with strong human impact (D).

\section{Materials and methods}

To understand the different perceptions of the park and to identify the important factors influencing the acceptance of the Stilfserjoch NP, we developed a questionnaire targeted at the local population. The survey was carried out by face-to-face interviews to obtain a high response rate (Bernard 1994). The questionnaire was designed in two languages, Italian and German, and tested in several pre-tests.

In spring 2001, we interviewed 1100 residents across the entire NP. The number of interviewees per municipality was calculated in relation to the total number of inhabitants of that municipality and the respective proportion of its area in the NP. We interviewed 400 people of a total population of 29413 in the eleven NP municipalities in South Tyrol. Here, the percentage of municipal area within the park ranged from $1.9 \%$ in Mals to $100 \%$ in Stilfs and Martell. We conducted 400 interviews in the ten NP municipalities in Lombardy with a total population of 28169 and an average percentage of municipal area within the park of $45.3 \%$. In Trentino, we interviewed 300 people of a total population of 4056 in the three NP municipalities. Here, the percentage of municipal area within the park ranged from $14.6 \%$ in Pellizzano to $69.2 \%$ in Pejo.

The main demographic data from the survey was compared with the official national statistics ASTAT (Provincial Statistics Institute of South Tyrol) and ISTAT (National Statistical Institute of Italy). The focus was on age, with three different classes ('up to 25', '25-55', '55 or older'), and gender. The characteristics of the respondents deviate slightly but not significantly from the official national statistics, mainly in young interviewees (up to 25 years) being underrepresented $(-7.8 \%)$.

For our acceptance study, interviewees were selected randomly and each interview was agreed by telephone. The high response rate $(93.5 \%)$ was achieved by faceto-face interviews. Advantages of this technique are: 1) knowing for certain who answers the questions, 2) excluding influences of other persons, 3) the possibility to ask for more complete information if a respond- 
ent does not understand a question, 4) interviewees probably take more time than with other questioning techniques - e.g. by mail or phone call (Bernard 1994).

Each questionnaire contained five classes of questions on 1) the attitude towards nature, 2) the efficiency and quality of the NPA, 3) the attitude towards management, 4) the effects on the interviewee and on the local population, and 5) socio-demographic data. The central question for the statistical analyses is the 'snap election' question ('Sonntagsfrage') - 'If you had to vote on the continued existence of the Stilfserjoch NP next Sunday, how would you vote?'. With the discriminant analysis we classified each interviewee as 1) supporter, 2) sceptic or 3) opponent, using any additional information from the interviewees as independent variables.

The procedure generated discriminant functions based on linear combinations of the predictor variables that provide the best discrimination between the groups. To avoid multicollinearity between the selected factors, stepwise discriminant analysis was employed. Consequently, we built a model for group membership prediction based on observed characteristics. The decisions of the non-voters cannot be predicted by the variables used, therefore this group was excluded from the modelling approach.

In 2009, a pre-test of the survey among one tenth of the park population was conducted to evaluate changes concerning the 'snap election question' as well as attitudes towards the zoning process. The full survey will be repeated in 2011. On the basis of the pre-test, we were able to detect trends within the last eight years. However, statistical analyses are conducted with the full survey of 2001 because of the small number of interviewees in 2009.

\section{Results}

Figure 2 displays the distribution of the answers to the 'snap election' question ('Sonntagsfrage') from the 1029 interviews in 2001 and the pre-test in 2009. In the pre-test of 2009, the number of 'sceptics' decreased by $22 \%$ while all other groups increased ('supporters' $+11 \%$; 'opponents' $+2 \%$; 'non-voters' $+9 \%$ ). The question 'Have you been involved in the planning process for the park zoning?' was added in the pre-test 2009 to evaluate the perception of the zoning process of the NP by the local population within the last eight years. Interestingly, only 4\% confirm involvement and any uptake of their opinion. Another 18\% confirm their involvement, but do not think that their opinions have been taken into account. Nearly one third of the interviewees $(32 \%)$ state that they have not been involved in the planning process and the remaining $46 \%$ claim ignorance of the park zoning.

Identification of decisive influence factors for the NP's acceptance was based on the full survey in 2001. For discrimination, the 'snap election' question was

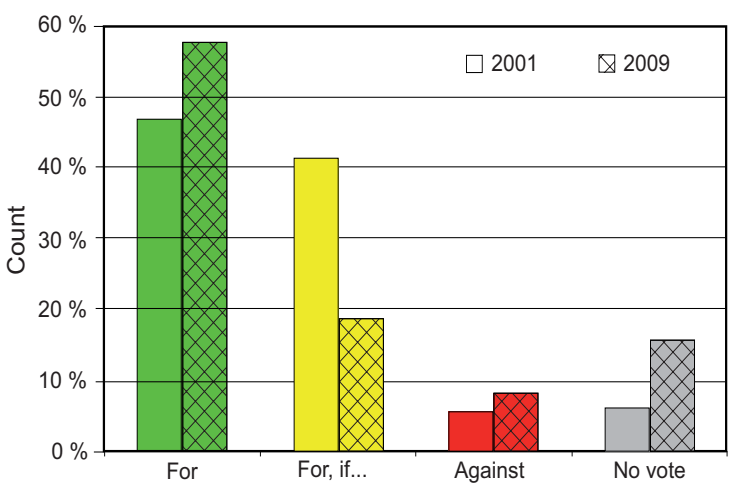

Figure 2 - Results from the survey in 2001 and the pre-test in 2009 on the 'snap election' question

employed as dependent variable for the discriminant analysis and all answers serve as independent variables. In this explorative study, a total of 70 independent variables were employed and 718 observation units without missing values were available. The canonical correlation, which measures the association between the discriminant scores and the groups, reached 0.68. The first canonical variable accounted for $88 \%$ of the spread and was highly significant $(\mathrm{p}<0.001)$.

The average discriminant score was -0.750 for the group of supporters ('For'), 0.596 for the group of sceptics ('For, if new demarcation and zoning'), and

Table 1 - The overall classification result of the stepwise discriminant analysis using all answers given as independent variable

\begin{tabular}{|l|l|r|r|r|}
\hline \multirow{2}{*}{ Vote about the continued existence } & \multicolumn{3}{l|}{ Predicted group } \\
\cline { 3 - 5 } \multicolumn{2}{|l|}{} & For & \multicolumn{1}{l|}{ For, if... } & \multicolumn{1}{l|}{ Against } \\
\hline \multirow{3}{*}{$\begin{array}{l}\text { Count } \\
(\%)\end{array}$} & For & $353(81.0 \%)$ & $80(18.3 \%)$ & $3(0.7 \%)$ \\
\cline { 2 - 5 } & For, if new demarcation and zoning & $99(26.6 \%)$ & $176(50.9 \%)$ & $71(20.5 \%)$ \\
\cline { 2 - 5 } & Against & $0(0.0 \%)$ & $10(20.4 \%)$ & $39(79.6 \%)$ \\
\hline $68.4 \%$ of original grouped cases are classified correctly \\
\hline
\end{tabular}

Table 2 - The stepwise discriminant analysis revealed 11 significant variables for the separation of the different groups. The standardized coefficients of the discriminant function describe the relative contribution of the variable to the overall discrimination

\begin{tabular}{|l|l|}
\hline \multicolumn{2}{|l|}{ Standardized canonical discriminant function coefficients } \\
\hline $\begin{array}{l}\text { Q13i: In my opinion: effects on me } \\
\text { (1 to 5: 1=only advantages, 5=only disadvantages) }\end{array}$ & +0.345 \\
\hline $\begin{array}{l}\text { Q3: Is it meaningful to place selected areas under protection? } \\
\text { (1 to 5: 1=very meaningful; 5=not meaningful) }\end{array}$ & +0.335 \\
\hline $\begin{array}{l}\text { Q13f: In my opinion: effects on the local population in general } \\
\text { (1 to 5: 1=only advantages, 5=only disadvantages) }\end{array}$ & +0.296 \\
\hline $\begin{array}{l}\text { Q9: Would you allow hunting within the NP Stilfserjoch? } \\
\text { (1=no, 2=for controlling game, 3=for certain kinds of game, 4=yes) }\end{array}$ & +0.265 \\
\hline $\begin{array}{l}\text { Q16: Age } \\
\quad \overline{1}\end{array}$ & +0.154 \\
\hline $\begin{array}{l}\text { Q19c: Are you a hotel keeper? } \\
\text { (0=no, 1=yes) }\end{array}$ & -0.112 \\
\hline $\begin{array}{l}\text { Q11k: In case of zoning, in which area would you allow mining? } \\
\text { (1=core zone, 2=margin zone, 3=only outside the NP) }\end{array}$ & -0.139 \\
\hline $\begin{array}{l}\text { Q11f: In case of zoning, in which area would you allow hunting? } \\
\text { (1=core zone, 2=margin zone, 3=only outside the NP) }\end{array}$ & -0.150 \\
\hline $\begin{array}{l}\text { Q19a: Are you a farmer? } \\
\text { (0=no, 1=yes) }\end{array}$ & -0.153 \\
\hline $\begin{array}{l}\text { Q10h: Would you allow access by car in an ideal NP? } \\
\text { (1=yes, 2=with restrictions, 3=no) }\end{array}$ & -0.184 \\
\hline $\begin{array}{l}\text { Q14: Cultural group } \\
\text { (1=German speaker, 2=ltalian speaker) }\end{array}$ & -0.269 \\
\hline
\end{tabular}


Table 3 -Classification results of discriminant analysis for separation of the two groups: supporter (FOR) and sceptic (FOR, IF...)

\begin{tabular}{|l|l|l|r|}
\hline \multirow{2}{*}{ Vote about the continued existence } & \multicolumn{2}{l|}{ Predicted group } \\
\cline { 3 - 4 } & For & For, if... \\
\hline $\begin{array}{l}\text { Count } \\
(\%)\end{array}$ & For & $330(77.1 \%)$ & $98(22.9 \%)$ \\
\cline { 2 - 4 } & For, if new demarcation and zoning & $89(25.7 \%)$ & $257(74.3 \%)$ \\
\hline $\mathbf{7 5 . 8 \%}$ of original grouped cases are classified correctly \\
\hline
\end{tabular}

Table 4 - Standardized discriminant function coefficients for separating groups of supporters (for) from sceptics (for, if...). The strong factors deal with the effects on the local population, the cultural group, the age of the interviewee, the attitude towards cars in the NP, and the question about bunting

\begin{tabular}{|l|l|}
\hline Standardized canonical discriminant function coefficients \\
\hline $\begin{array}{l}\text { Q13f: In my opinion: effects on the local population in general } \\
\text { (1 to 5: 1 =only advantages, 5=only disadvantages) }\end{array}$ & +0.357 \\
\hline Q16: Age & +0.345 \\
\hline $\begin{array}{l}\text { Q9: Would you allow hunting within the NP Stilfserioch? } \\
\text { (1=no, 2=for controlling game, 3=for certain kinds of game, 4=yes) }\end{array}$ & +0.301 \\
\hline $\begin{array}{l}\text { Q13i: In my opinion: effects on me } \\
\text { (1 to 5: 1=only advantages, 5=only disadvantages) }\end{array}$ & +0.239 \\
\hline $\begin{array}{l}\text { Q13c: In my opinion: effects on farmers } \\
\text { (1 to 5: 1=only advantages, 5=only disadvantages) }\end{array}$ & +0.039 \\
\hline $\begin{array}{l}\text { Q4e: Do you go hunting (spare time)? } \\
\text { (0=no, 1 =yes) }\end{array}$ & -0.159 \\
\hline $\begin{array}{l}\text { Q10c: Would you allow skiing in an ideal NP? } \\
\text { (1=yes, 2=with restrictions, 3=no) }\end{array}$ & -0.178 \\
\hline $\begin{array}{l}\text { Q19c: Are you a hotel keeper? } \\
\text { (0=no, 1=yes) }\end{array}$ & -0.192 \\
\hline $\begin{array}{l}\text { Q1 1f: In case of zoning, in which area would you allow hunting? } \\
\text { (1=core zone, 2=margin zone, 3=only outside the NP) }\end{array}$ & -0.201 \\
\hline $\begin{array}{l}\text { Q10h: Would you allow access by car in an ideal NP? } \\
\text { (1=yes, 2=with restrictions, 3=no) }\end{array}$ & -0.264 \\
\hline $\begin{array}{l}\text { Q14: Cultural group } \\
\text { (1=German speaker, 2=ltalian speaker) }\end{array}$ & -0.315 \\
\hline
\end{tabular}

2.649 for the group of opponents ('Against'). This finding indicated that group means were well separated.

The classification result (Table 1) was satisfactory, more than two thirds of the originally grouped cases were classified correctly (68.4\%). In particular, $81 \%$ of the supporters and $79.6 \%$ of the opponents were classified correctly. The misclassified opponents were all assigned to the group of sceptics. The situation was similar for the supporters: only $0.7 \%$ or 3 out of 436 cases were misclassified as opponents, and the remaining $18.3 \%$ of the misclassifications were categorized as sceptics.

Table 2 displays the eleven variables with significant explanatory power to the discriminant function. Standardizing the coefficients allowed us to describe the relative contribution of each variable to the overall discrimination.

The sign of the coefficient indicates the contribution of a high or low score of the variable to individual decisions. According to the average discriminant score of each group, a positive (negative) sign, together with a high value of the variable, indicates that the interviewee belongs to the opponents (supporters). The magnitude of the coefficient determines how strong the variable contributes to a voting decision.
We defined variables with a standardized influence factor score above 0.25 as 'strong' factors and will describe them in more detail below. For details on questions please refer to the appendix. The highest value of 0.345 was assigned to question 13i. This attitude implies the importance of the benefit of the park for the individual. As a main result we record that nature protection is highly accepted if there are no personal impacts.

Question 3 reached an influence factor score of 0.335 and points to the importance of the attitude towards nature protection. Note that question 1 on personal interest in nature did not enter in the stepwise discriminant analysis. This result suggests that the general attitude is more significant than any personal interest in nature. The assessment whether the NP has advantages or disadvantages for the local population in general (question 13f) influenced the decision greatly. A special conflict point in the Stilfserjoch NP was shown up via question 9 whether hunting should be allowed within the park. People who would permit hunting voted against the continued existence of the protected area.

The mean probability of membership for each 'strong' factor is illustrated in Figure 3. There is a linear correlation between the answers to the questions and voting for the groups of supporters and opponents. Within these groups no indifferent behaviour was expected. However, in the case of the sceptics we identified no linearity or monotony. This characteristic reflects the indifferent and hardly predictable voting behaviour of this group.

The 'cultural group' factor (question 14) has a large negative standardized coefficient of the discriminant function and is described separately to emphasize particularities. This factor was introduced to analyse culturally and historically motivated differences between the mostly German-speaking part of South Tyrol and the mostly Italian-speaking parts of Trentino and Lombardy. To which extent did these differences affect the attitude to the NP?

The interviewees from the German-speaking part of the NP are most likely (probability of $41 \%$ ) to belong to the sceptics (Figure 4). The Italian speakers, on the contrary, have the highest probability (57\%) of being supporters of the Stilfserjoch NP. The probability of belonging to the group of opponents is $9 \%$ for the Italian part, while reaching $24 \%$ in the German part. Moreover, interviewees in the German part are clearly less likely to be among the supporters than those in the Italian part.

In order to investigate the support for the NP in more detail, we wanted to identify the decisive factors, especially those differentiating the supporters and sceptics, in a second analysis. Such findings might be of decisive in gaining acceptance of the NP: How to minimize scepticism? Table 3 summarizes the overall classification result for the differentiation of supporters and sceptics. 
Again eleven factors have significant explanatory power. Differences with the former discrimination (Table 3) are small. The resulting devaluation of question 3 indicates that information on the significance of protected areas is necessary to differentiate the opponents from the other two groups. The socio-demographic factor 'age' was a strong factor in this case and identified older people as 'sceptics'.

Summing up, compared to the most important factors separating all three groups of voters (Table 3), the differentiation of supporters and sceptics (Table 5) indicates three common 'strong' influence factors, of which question $13 \mathrm{f}$ about the 'effects on the local population' was the strongest, followed by question 14, the 'cultural group'. The third one was question 9 about 'hunting within Stilfserjoch NP'.

Note that except 'cultural group' and 'age', no other socio-demographic variable entered the discriminant analysis as a strong influencing factor. For detailed understanding of these factors we performed two more discriminant analyses - one for each cultural group with all answers of the questionnaire as independent variables and the 'snap election' question ('Sonntagsfrage') as dependent variable. Two common 'strong' influence factors for German-speaking and Italianspeaking interviewees emerged (Figure 5): 1) hunting and 2) effects on the local population. Within both ethnic groups, people who believe that the NP has many disadvantages for the population and who allow hunting in the park are highly sceptical about the NP. Among Italian speakers, effects on the individual is a decisive factor and older people are more sceptical than younger ones. German speakers are more focused on management issues: in an ideal NP, access by car should be regulated, as should be the management of alpine pastures and the collecting of mushrooms, berries and herbs.

\section{Discussion}

The results of the 'snap election' question reveal a small number of non-voters, which confirms studies from Feddersen and Pesendorfer (1999) and Hepburn et al. 2001 who found a large interest in the topic among locals.

Although more opponents were expected, the results indicate a lack of acceptance given the large group of sceptics $(41.3 \%)$. The voting behaviour of this group was ambivalent and therefore hardly predictable, which is quite plausible: sceptics stood out by their lack of a stable opinion on the continued existence of the NP. It is difficult to trace back the smaller number of sceptics in the 2009 pre-test (Figure 2) to the park zoning. First, the majority of the interviewees think that they were either not involved in the planning process or are not even aware of the park plan. Second, the park plan has not been implemented by the Italian government to date (March 2010), so neither positive nor negative effects are visible.

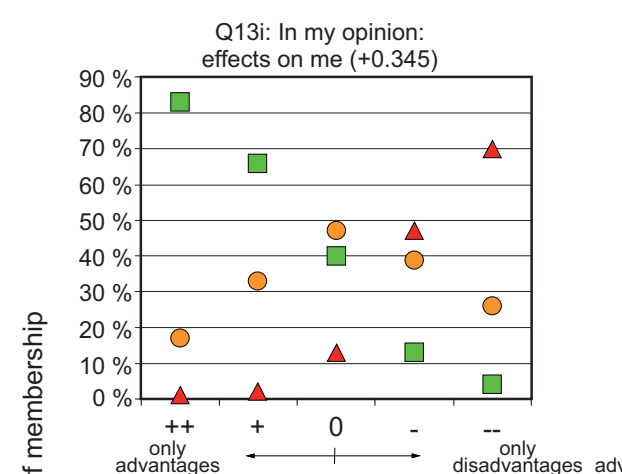

Q3: Is it meaningful to place selected areas under protection? $(+0.335)$

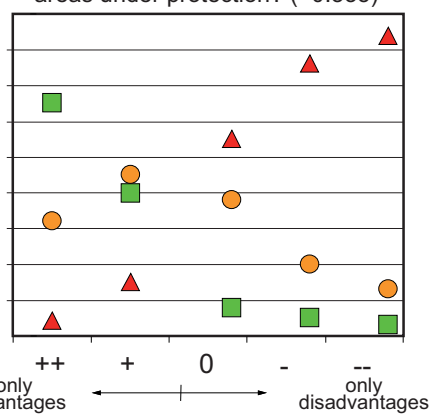

Q13f: In my opinion: effects on the local population in general $(+0.296)$

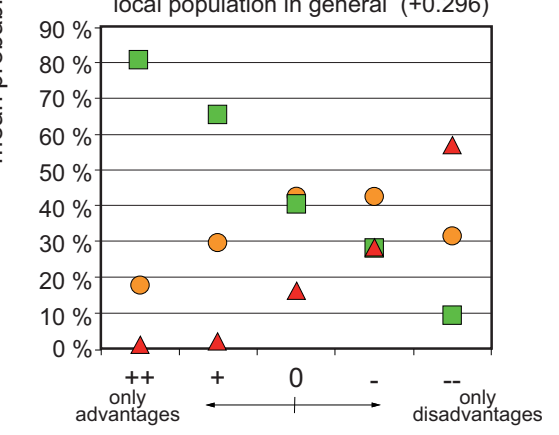

Q9:Would you allow hunting within the NP Stilfserjoch? $(+0.265)$

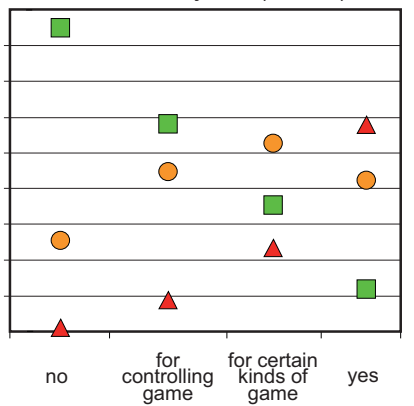

Figure 3 - The mean probability of membership regarding the strongest positively correlated factors to the groups of supporters $(\square)$, sceptics (O), and opponents $(\Delta)$

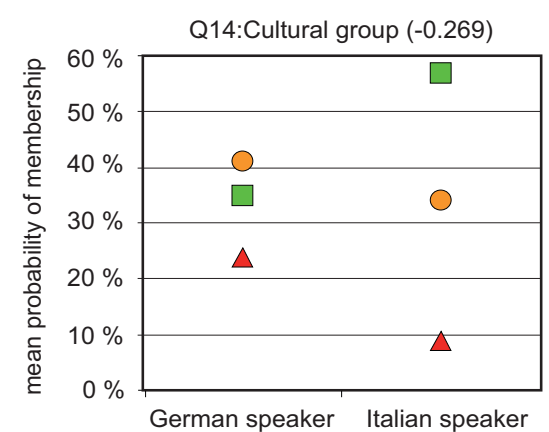

Figure 4 - The mean probability of members of each 'cultural group' belonging to the groups of supporters $(\square)$, sceptics (O), and opponents ( $\Delta$ )

When ranking the determinants for acceptance of the $\mathrm{NP}$, the dominant reasons for refusal are personal or general disadvantages for the locals. This finding is consistent with the results for protected areas on all scales (Bauer 2005; Colchester 2004; Collin 1990; Job 1996; Trakolis 2001a; Trakolis 2001b). Due to a lack of interest in environmental protection, the presence of a reserve does not mean any perceived improvement of quality of life. Our results indicate a rather positive attitude of hotel proprietors and farmers, who may have an economic benefit from the label 'national park'. Alkan et al. 2009 report for the Kovada Lake National Park in south-western Turkey: ' $[. .$.$] As a matter$ of fact, $75 \%$ of local people, who have many losses of benefit (authors' note: economic benefit) [...] and whose losses have not been compensated [...] protest against its (authors' note: national park) application.' Additionally, land use and hunting were found to contribute significantly to the formation of 'supporters' and 'opponents'. Overall, the results correspond nicely 


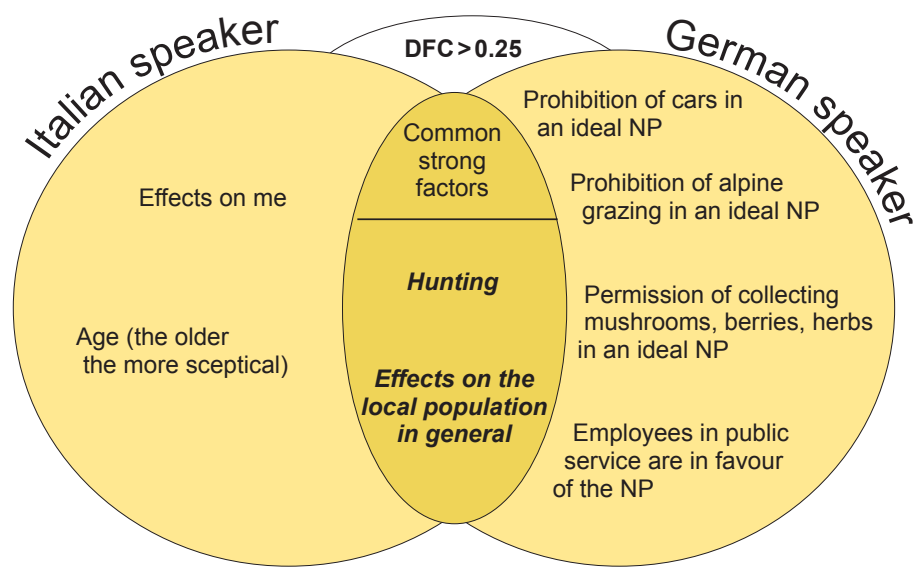

Figure 5 - The summary of two separate discriminant analyses for both cultural groups reveals two common strong influence factors to classify voting behavior: 1) bunting and 2) effects on the local population

to our study, although environmental and social conditions clearly differ. Similarly, Bonaiuto et al. 2002 analysed attitudes in two different Italian national parks and found more negative attitudes towards the national parks among locals who were more involved in local economic activities. A study on national parks in the Alps was conducted by Dorić (2005) who analysed attitudes towards five Austrian nature reserves with respect to participation in the planning process. It found that protected areas based on voluntary and deliberate involvement of the local population ('bottom-up' designation) clearly enjoy higher acceptance than those designated 'top-down'. Opposition grew mainly through actions such as expropriation, which discriminated locals. As a result, in discussions on the acceptance of conservation measures in Switzerland (Schenk et al. 2007), many people tend to assume that economic factors are most important. However, Schenk et al. (2007) also state that communication between those affected and the authorities seems to be at least as if not more important than economic factors. Our findings back this up where scepticism stems mostly from perceived potential negative effects on the local population in general and on hunting. These are not really economic factors but principles of a free society, i.e. solidarity and freedom.

The residents of the Stilfserjoch NP differ from those investigated in other studies in their historical and cultural background which adds further value to this study. Markusse (1991) described differences in the positions in society of the members of the different ethnic groups within South Tyrol and cultural discrepancies were assumed to be of minor importance at the beginning of the study. However, as our findings demonstrate, such social and culture-specific attitudes may cause concerns about the NP. To overcome such objections, the NPA needs to analyse cultural variety among the park's residents carefully and take it into account in their dealings with them. Finally, the high impact of the attitude towards hunting within the Stilfserjoch NP implies that one point of conflict, which leads either to a restriction of leisure activities or intervenes in a long standing tradition, is enough to impair acceptance of a nature reserve. Rösener (complex relations between hunting, nature protection and environmental awareness, which are not yet understood in detail. Our results are consistent with the findings of previous investigations on hunting (Burns et al. 2003; Conforti \& Cesar Cascelli de Azevedo 2003). In protected areas with a 'hunting conflict', a compromise with the local population has to be found to win their acceptance of the reserve in the long run.

Regardless of whether the discriminant analysis uses three groups for classification (supporter, sceptic, opponent) or two groups (supporter, sceptic), almost the same factors for discrimination emerge as important. This finding suggests that one strategy is sufficient to increase the acceptance of both the opponents and the sceptics. One fundamental goal in conservation planning is to implement nature reserve designs that protect those lands that are most valuable for conservation and at the same time to avoid the inclusion of land that is valuable for other stakeholders (BojorquezTapia et al. 2004).

\section{Management implications}

According to our findings, opinion forming within the local population happens in three steps:

1) 'environmental education' is necessary to establish a positive basic attitude towards nature, which is a decisive factor in our analysis. In addition to family and school, the NPA should take responsibility for environmental education. However, the group of sceptics shows a highly indifferent behaviour. 'Environmental education' is a necessary basis for this group but insufficient for convincing them in the long run.

2) the 'social needs' of the residents must be investigated and identified. The population concerned must not be split by the NP. It is particularly important to study the characteristics of different cultural groups and the effects on the local population.

3) to gain high acceptance, it is also essential to minimize personal disadvantages by relating the NP to everyone in a third step at the level of 'personal needs'.

Ranking social needs as step two and personal needs as the final third step is plausible, as pseudo-solidarity often severely biases response behaviour (Tischner et al. 1994; Oehler 2003). We think that negative effects on the individual will lead to reduced acceptance in the long run, even if the local population in general agrees to the reserve. The main sphere of action of the NPA within these three steps should be at the levels of social and personal needs, with acceptance by society highly influencing personal attitudes (French et al. 
1998). Moreover, if acceptance of the reserve is to improve, the local population must benefit from the conservation activities (Collin 1990; Grainger \& Grainger 2003; Hamin 2002). In this sense, economic benefits play an important role alongside psychological, sociological and political issues (Hamin 2002). According to Bittner (2000), environmental education would improve the attitude towards nature protection. However, in our results, environmental education is clearly less important and a 'basic requirement'. According to Maslow's hierarchy of requirements (Maslow 1985), a basic requirement must be given but is usually not sufficient for reaching the final goal.

At the Stilfserjoch NP, various concerns about management issues exist. In the present situation of the Stilfserjoch NP, the disadvantages for individuals and for the local population in general are the main causes for a negative attitude. Examples indicate that zoning can meet such demands (Bojorquez-Tapia et al. 2004; Gafta \& Pedrotti 1997; Hepcan 2000; Yamaki et al. 2003). The design of the park plan and the zoning system must be communicated to the park residents and to all park users (Downie 1984). A transparent decision tree leads to broad agreement and thus to the optimum acceptance of the protected area. If the NPA succeeds in convincing the 'sceptics' by fulfilling their social and personal needs, acceptance could reach $80 \%$ of the local population. If it fails, the NPA faces a refusal by nearly $50 \%$ of the park residents (Figure 2). Although the pre-test in 2009 counts $58 \%$ of the population as 'supporters' of the Stilfserjoch NP, the percentage of 'sceptics' and 'non-voters' is still high (34\%). Moreover, the reduction of sceptics could hardly be attributed to the park zoning if one considers that $78 \%$ of those interviewed think that they were not involved in the planning process or even claim ignorance of the park plan, which has not become operative to date (March 2010). However, all legal prerequisites have been fulfilled by the NPA and implementation by law is now up to the Italian Department of the Environment. We intend to conduct another full survey after successful implementation of the park plan to evaluate the planning process and the effects of the park plan on perceptions within the population.

\section{Acknowledgments}

The analysis of the field work and the publication of the results were carried out with financial support from 'Alpine Space - Man and Environment', a research focus of the University of Innsbruck. We would like to thank the National Park Administration of the Stilfserjoch NP, in particular director Dr Wolfgang Platter, for support and necessary background information. Finally, we are grateful to the local population for their cooperation.

\section{References}

Alkan, H., M. Korkmaz \& A. Tolunay 2009. Assessment of primary factors causing positive or negative local perceptions on protected areas. Journal of Environmental Engineering and Landscape Management 17, 1:20-27.

Bauer, N. 2005. Attitudes towards wilderness and public demands on wilderness areas. In: Kowarik, I. \& S. Körner (eds.), Wild Urban Woodlands: pp. 47-66.

Bernard, H.R. 1994. Research Methods in Anthropology: Qualitative and Quantitative Approaches. Thousand Oaks, CA Sage.

Bittner, A. 2000. Wirkungs- und Konzeptevaluation von Umweltbildung am Beispiel des Nationalparks Harz/Niedersachsen. Allgemeine Forst- und Jagdreitung 71: 195-204.

Bojorquez-Tapia, L.A., H. De La Cueva, S. Diaz, D. Melgarejo, G. Alcantar, M.J. Solares, G. Grobet \& G. Cruz-Bello 2004. Environmental conflicts and nature reserves: Redesigning Sierra San Pedro Martir National Park, Mexico. Biological Conservation 117: 111-126.

Bonaiuto, M., G. Carrus, H. Martorella \& M. Bonnes 2002. Local identity processes and environmental attitudes in land use changes: The case of natural protected areas. Journal of Economic Psychology 23, 5: 631-653.

Brand, L.A. 2001. Displacement for Development? The Impact of Changing State-Society Relations. World Development 29: 961-976.

Burns, G.L. \& P. Howard 2003. When wildlife tourism goes wrong: a case study of stakeholder and management issues regarding Dingoes on Fraser Island, Australia. Tourism Management 24: 699-712.

Campbell, D.J., H. Gichohi, A. Mwangi \& L. Chege 2000. Land use conflict in Kajiado District, Kenya. Land Use Policy 17: 337-348.

Chapman, D. 2003. Management of national parks in developing countries: A proposal for an international park service. Ecological Economics 46: 1-7.

Colchester, M. 2004. Conservation policy and indigenous peoples. Environmental Science Policy 7: 145-153.

Collin, G. 1990. Rural society and protected area: which dialogue? The case study of Cevennes National Park and Biosphere Reserve (France). Landscape Urban Planning 19: 173-180.

Conforti, V.A. \& F. Cesar Cascelli de Azevedo 2003. Local perceptions of jaguars (Panthera onca) and pumas (Puma concolor) in the Iguacu National Park area, south Brazil. Biological Conservation 111: 215-221.

DeBattaglia, F. 1974. Stelvio - un parco per l'Europa. Club Alpino Italiano / Commissione Centrale Protezione Natura Alpina, Trento.

Doric 2005. The role of citizen participation in the establishing of national parks in Austria. Master thesis, Roskilde University, Denmark.

Downie, B.K. 1984. Reflections on the national park zoning system. Operational Geographer 3: 15-19.

Feddersen, T.J. \& W. Pesendorfer 1999. Abstention in elections with asymmetric information and diverse preferences. The American Political Science Review 93: 381-398. 
Ferraro, P.J. 2002. The local costs of establishing protected areas in low-income nations: Ranomafana National Park, Madagascar. Ecological Economics 43: 261-275.

French, P.A. 1998. Individual and Collective Responsibility. Rochester, Vermont.

Gafta, D. \& F. Pedrotti 1997. Environmental units of the Stelvio National Park as basis for its planning. Oecologia Montana 6: 17-22.

Getzner, M. \& M. Jungmeier 2002. Conservation policy and the regional economy: the regional economic impact of Natura 2000 conservation sites in Austria. Journal for Nature Conservation 10: 25-34.

Grainger, J. 2003. 'People are living in the park'. Linking biodiversity conservation to community development in the Middle East region: A case study from the Saint Katherine Protectorate, Southern Sinai. Journal of Arid Environments 54: 29-38.

Hamin, M. 2002. Western European approaches to landscape protection: A review of the literature. Journal of Planning Literature 16: 339-358.

Hepburn, C.G. \& J. Barling 2001. To vote or not to vote: Abstaining from voting in union representation elections. Journal of Organizational Behavior 22: 569-591.

Hepcan, S. 2000. A methodological approach for designating management zones in Mount Spil National Park, Turkey. Environmental Management 26: 329-338.

Job, H. 1996. Grossschutzgebiete und ihre Akzeptanz bei Einheimischen: das Beispiel der Nationalparke im Harz. Geographische Rundschau 48: 159-165.

Markusse, J. 1991. Autonomy in a multi-ethnic region: the case of South Tyrol. Nederlandse Geografische Studies 137: 130-152.

Maslow, A. 1985. Toward a Psychology of Being. Frankfurt, Germany.

Oehler, K.T. 2003. Rivalry as a taboo. Dynamische Psychiatrie 36: 19-38.

Rösener, W. 2004. Die Geschichte der Jagd: Kultur, Gesellschaftund Jagdwesen im Wandel der Zeit. Düsseldorf / Zürich.

Schenk, A., M. Hunziker \& F. Kienast 2007. Factors influencing the acceptance of nature conservation measures - A qualitative study in Switzerland. Journal of Environmental Management 83: 66-79.

Seeland, K. 2000. National Park policy and wildlife problems in Nepal and Bhutan. Population \& Environment 22: 43-62.

Singh, K.R. 1996. People's participation in management of protected area. Indian Forester 122: 1068-1072.

Sträde, S. \& F. Helles 2000. Park-people conflict resolution in Royal Chitwan National Park, Nepal: Buying time at high cost? Environmental Conservation 27:368-381.

Terstad, J., 1999. Swedish experiences of incentives for the protection of nature. Science of the Total Environment 240: 189-196.

Tischner, J., G.F. McLean \& J. Zycinski 1994. The Philosophy of Person: Solidarity and Cultural Creativity: Polish Philosophical Studies. I. Council for Research in Values and Philosophy, Washington.
Trakolis, D. 2001a. Local people's perceptions of planning and management issues in Prespes Lakes National Park, Greece. Journal of Environmental Management 61: 227-241.

Trakolis, D. 2001b. Perceptions, preferences, and reactions of local inhabitants in Vikos-Aoos National Park, Greece. Journal of Environmental Management 28: 665-676.

Treu, M.C., M. Magoni, D. Palazzo \& F. Steiner 2000. Sustainable landscape planning for Cremona, Italy. Landscape Urban Planning 47: 79-98.

Wallner, A., N. Bauer \& M. Hunziker 2007. Perceptions and evaluations of biosphere reserves by local residents in Switzerland and Ukraine. Landscape Urban Planning 83: 104-114.

West, P. \& D. Brockington 2006. An anthropological perspective on some unexpected consequences of protected areas. Conservation Biology 20: 609-616.

White, P.C.L. \& J.C. Lovett 1999. Public preferences and willingness-to-pay for nature conservation in the North York Moors National Park, UK. Journal of Environmental Management 55: 1-13.

Yamaki, K., J. Hirota, S. Ono, Y. Shoji, T. Tsuchiya \& K. Yamaguchi 2003. A method for classifying recreation area in an alpine natural park using recreation opportunity spectrum. Journal of the Japanese Forestry Society 85: 55-62.

\section{Authors}

\section{Georg Leitinger - corresponding author georg.leitinger@uibk.ac.at}

\section{Janette Walde}

Department of Statistics, University of Innsbruck, SOWI Building, Universitätsstraße 15, 6020 Innsbruck, Austria.janette.walde@uibk.ac.at

\section{Roberta Bottarin}

Institute for Alpine Environment, European Academy Bolzano/Bozen, Viale Druso 1, 39100 Bolzano/ Bozen, Italy. roberta.bottarin@eurac.edu

\section{Gottfried Tappeiner}

Department of Economic Theory, Economic Policy and Economic History, University of Innsbruck, SOWI Building, Universitätsstraße 15, 6020 Innsbruck, Austria.gottfried.tappeiner@uibk.ac.at

\section{Ulrike Tappeiner ${ }^{1}$}

ulrike.tappeiner@uibk.ac.at

1- University of Innsbruck, Institute of Ecology, Sternwartestraße 15, A-6020 Innsbruck, Austria;

- European Academy Bolzano/Bozen (EURAC), Institute for Alpine Environment, Viale Druso 1, 39100 Bolzano/Bozen, Italy. 